\title{
The Influence of Scientific Approach on Increased interest, creativity and learning outcomes: an Action Class Research
}

\author{
Andi Nur Reski \\ andinurreski66@gmail.com \\ English Department, Faculty of Teacher Training and Education, University of \\ Muhammadiyah Makassar, Indonesia \\ Received: August 3, 2020 \\ Received in Revised: August 11, 2020 \\ Accepted: August 13, 2020
}

\begin{abstract}
Class Action Research (CAR) was conducted to analyze the increase of interest, creativity and interest, creativity, and learning outcomes of students in the Mattayeom 4 class Phatanakansuksa Foundation School Thailand by implementing the Scientific approach method. During the observation and review with the English teacher Mattayeom 4, the researcher was able to describe the profile of student learning outcomes in grade 1 as a class with great potential but not well-honed. The low interest of students in this learning process can result in a learning process that is not optimal so that the results obtained are not optimal. The results of the implementation of classroom action research in the Mattayeom 4/2 Phatanakansuksa Foundation School's Real Work Lecture program which shows an increase in learning outcomes through a direct learning process applied by teachers/researchers.
\end{abstract}

Keywords: Classroom Action Research, Scientific Approach, Learning Outcome

\section{Introduction}

Scientific Approach Method is an approach used in the learning process. This approach was developed from the scientific method which was originally widely used in learning science or natural sciences (Nugraha \& Suherdi 2017). Currently, the scientific approach is developed to be used in almost all subjects, especially in the 2013 curriculum the scientific approach to subjects was initially applied to science subjects, but now it is developing in other subjects, even integrative thematic learning.

The Classroom Action Research (CAR) which was conducted at Phatanakansuksa Foundation School with the subject of the Mattayeom 4/2 class began by making preliminary observations of the learning process in the classroom which was conducted on November 19, 2019. On the first day, the writer observed the extent of the ability of the Mattayeom 4 class students in lessons English. The author also observes the learning process which includes the methods and media used by the English teacher and observes the attitudes of students during the lesson.

In this class, there are 20 students consisting of 9 boys and 11 girls. In the teaching and learning process carried out, a learning model is chosen which is considered appropriate to the situations and conditions of the students. One of the methods applied is the Scientific Approach method.

The learning process takes place by prioritizing giving action directly to students. In accordance with the research to be carried out, namely Classroom Action Research (CAR). Giving direct treatment in the form of this action is expected to further improve student learning outcomes, student activities, student creativity, especially in increasing student learning motivation. 
Thus, the researcher considers the need for a learning method or model that is given in the form of an action. So that learning in the classroom also does not take place monotonously and occurs in only one direction, namely from teacher to student. But more than that, the researcher hopes that by applying this learning model, it is hoped that two-way communication will occur between teacher to student and student to teacher.

In the teaching method of the Scientific Approach, students are formed in several groups, then from these groups students are invited to be more creative, innovative and have a strong sense of togetherness in their respective teams. In the learning process, there are several aspects that are carried out, namely, student interest, student attention, student participation, and student presentations in class. The learning process in the classroom takes place in a cycle. There are several activities that need to be considered by a teacher in the process of strategy observation, modeling, working in pairs/groups, practicing.

Through this learning model, it is hoped that student learning outcomes will increase. Therefore, the researcher felt the need to use the Siantifik Approach method in class VII 1, because by looking at the previous learning conditions, and seeing the condition of the students in the class was very heterogeneous.

\section{Learning Outcomes Profile}

To create a quality human being, of course, it cannot be separated from the world of education as well as having a good quality. English education in schools is carried out and has the following objectives: (a) Developing students' abilities and skills through studying the types, properties, functions, processes, and techniques of an English learner. (b) Developing intellectual abilities, imagination, expression, creative sensitivity, skills, and appreciating learning outcomes and skills from various regions of the archipelago and abroad. (c) Develop a professional attitude, cooperation, tolerance, and leadership (Wicaksono \& Roza, 2015).

During the observation and review with the English teacher Mattayeom 4, the researcher was able to describe the profile of student learning outcomes in grade 1 as a class with great potential but not well-honed. The low interest of students in this learning process can result in a learning process that is not optimal so that the results obtained are not optimal. This shows that if we want to improve student learning outcomes then we must be able to increase student interest, in something then interest will be a strong motive to relate more actively to those that interest them and will make students more creative. Interest will increase if channeled into an activity. The attachment to these activities will further foster students' interest and creativity.

Based on the profile of the learning process and learning outcomes, the formulation of the problem of this study is "Can the use of the Scientific Approach method increase interest, creativity and learning outcomes in English for students in class Mattayeom 4 (1 SMA) phatanakansuksa Foundation School Thailand?"

\section{Forms of Action to Solve Problems According to Problems}

The form of action taken in solving problems in accordance with the problems in the Classroom Action Research (CAR) is learning using the Scientific Approach Method. By using this Scientific Approach method, it is hoped that it can increase interest, creativity and interest, creativity, and learning outcomes of students in the Mattayeom 4 class (1 SMA) Phatanakansuksa Foundation School Thailand.

Based on the problems faced by Phatanakansuksa Foundation School students, the authors are interested in improving learning by conducting classroom action research. The initial improvement made was the application of a learning model that prioritizes student activity 
and provides opportunities for students to develop their full potential. The learning method in question is the Scientific Approach Method.

\section{Overview of the Scientific Learning Approach}

The scientific approach has been used in education in America in the late 19th century where at that time science learning emphasized formalistic laboratory methods which were then directed at scientific facts. The scientific approach has actually been used in the curriculum in Indonesia with the term learning by doing which is known as active student learning in carrying out learning activities that were formally adopted in the 1975 curriculum.

Firman, Baedhowi, \& Murtini, (2018) suggest that the purpose of the scientific approach in learning, among others, is to improve the thinking skills of students, form the ability to solve problems systematically, create learning conditions so that students feel that learning is a need, train students in suggesting ideas, improve student learning outcomes, and develop the character of students.

The learning process using a scientific approach is directed so that students are able to formulate problems (by asking a lot of questions), not just solving problems by answering them. The learning process is expected to be directed to train analytical thinking (students are taught how to make decisions) not mechanistic thinking (routinely only by listening and memorizing (Chu, Tse \& Chow 2011).

The steps of a scientific approach in the learning process include digging up information through observation, asking, experimenting, then processing data or information, presenting data or information, followed by analyzing, reasoning, then concluding, and creating (Basiroh, 2017). For certain subjects, materials, or situations, it is very possible that this scientific approach is not always appropriate to be applied procedurally. In conditions like this, of course, the learning process must still apply scientific values or characteristics and avoid values or non-scientific characteristics. The scientific approach in the scientific approach is presented as follows.

\section{Observation}

The activity of observing in learning is carried out by taking steps which include; (a) Determine the object to be observed. (b) Making observation guidelines in accordance with the scope of the object being observed. (c) Determine clearly what data needs to be observed, both primary and secondary. (d) Determine where the object to be observed. (e) Clearly determine how the observations will be made in order to collect data so that it runs easily and smoothly. (f) Determine how and record observations, such as using notebooks, cameras, tape recorders, video recorders, and other writing instruments.

\section{Questioning}

Effective teachers are able to inspire students to improve and develop their attitudes, skills, and knowledge. When the teacher asks, at that time the teacher guides or guides their students to learn well. When the teacher answers students' questions, at that time the teacher encourages students to be good listeners and learners.

\section{Gathering Information}

The activity of "gathering information" is a follow-up to asking questions. This activity is carried out by exploring and gathering information from various sources in various ways. For this reason, students can read more, pay attention to phenomena or objects that are more accurate, or even carry out experiments (Dessy, 2014). 


\section{Associating/Processing Information/Reasoning}

Associating activities in learning as stated in Regulation of the Minister of Education and Culture No. 81a of 2013 is processing information that has been collected, either limited to the results of collecting or experimental activities or the results of observing and gathering information.

\section{Communicate}

In the scientific approach, the teacher is expected to provide opportunities for students to communicate what students have learned. This activity is carried out by writing down or telling what is found in the activities of seeking information, associating, and finding patterns. These results are presented in class and assessed by the teacher as the learning outcomes of these students or groups of students.

As subjects in this study were the Mattayeom 4/2 class Phatanakansuksa Foundation School, Satun Thailand for the 2019-2020 academic year with 20 students, consisting of 11 female students and 9 male students.

This research was conducted in the Matayyeom 4/2 class Phatanaknsuksa Foundation School, Satun Thailand for English subjects. This research is action research (action research) which was conducted for 5 months starting from 19 November 2019 to 23 March 2020.

After observing for 1 day and consulting with the supervisor, the researcher finally began to make learning tools suitable for application in class VIII A. The steps taken in making learning devices include:

\section{Lesson Plan Implementation and Evaluation}

The lesson plan (Lp) is a reference for researchers to conduct classroom action research which is divided into two cycles and uses different Lp in each meeting (Santoso, 2010). Evaluation is carried out at the end of each cycle, namely at the fifth meeting.

\section{Meeting 1}

At the first meeting held on November 22, 2019, at 14:40 to 15.30 At the initial activity, the researcher opened greetings, prayers led by one of the students, checked student attendance, and made introductions between students and teachers. Then motivate students by explaining the importance of the material to be studied to understand the next material and apply it to daily life and explain the competencies that must be achieved in learning activities and explain learning procedures with the scientific approach to learning model.

\section{Meeting 2, 3 and 4}

The second meeting was held on 29 November 2019, the third meeting was on 13 December 2019 and the fourth meeting was on 20 December 2020 at 14:40 to 15.30 . In the initial activity which was carried out for about 5 minutes, the teacher opened a greeting and prayer lesson led by one of the students, checked the attendance of the students, and conditioned the students to be ready to take part in learning.

Furthermore, in the core activity, the teacher provides material on "Part of Speech (focus Speaking)" with material focus on the use of nouns and adjectives at the second meeting and focus on pronouns and adverbs at the third meeting with focus speaking and making positive, negative and interrogative sentences. The teacher explains the use of nouns, pronouns, and adverbs, at the second and third meetings, then invites students to make sentences about the material using speaking so that students get used to practicing English. 
When giving explanations, students pay close attention then students will be given a few minutes to note what has been understood then at the end of the activity the teacher will assign each student to give positive, negative, and interrogative sentences related to nouns, adjectives, pronouns, and adverbs. And at the fourth meeting, the teacher evaluates the extent to which students understand by giving assignments to students to make sentences by speaking, and when class ends the teacher closes the meeting with prayers and greetings. The teacher always provides vocabulary at the end of the meeting every week which is given to students so that students have an increase in English vocabulary.

\section{Meeting 5 and 6}

The fifth meeting was held on December 6, 2019, and the sixth meeting was held on December 13, 2019, at 14:40 to 15.30 . The initial activity begins with opening greetings, a prayer led by one of the students, and other activities such as in the initial activities in the previous meeting.

The material in the fifth and sixth meetings is "Describing Thing (focus speaking)". At the fifth meeting, the teacher gave an explanation of describing things and how to describe objects in English and provided vocabulary related to describing things. At the sixth meeting, the teacher reviewed the steering material students were asked to pay attention to objects in class and mention them in English. Then link it to the previous material at meetings 2,3 and 4. For assignments students are asked to choose one object in the class then describe the object using the vocabulary given in the previous meeting then speak and the meeting ends with prayer and greeting.

\section{Meeting 7 and 8}

The seventh and eighth meetings will be held on December 27 and January 3, 2020, at 14:40 to 15.30. The initial activity begins with opening greetings, a prayer led by one of the students, and other activities such as in the initial activities in the previous meeting. The material at the seventh and eighth meetings is reading text (narrative). In this material, the teacher explains about narrative text by giving examples of narrative text to students then explains what narrative text is and its parts. At the eighth meeting, students were asked to work on assignments in guidebooks related to answering questions about narrative material. In this material students are trained to be more active in reading and to be able to distinguish between the narrative text sections. Then the meeting always ends with the meeting ending with prayer and greeting.

\section{Meeting 9 and 10}

The ninth and tenth meetings will be held on January 10 and 17, 2020 from 14:40 to 15.30. The initial activity begins with opening greetings, a prayer led by one of the students, and other activities such as in the initial activities in the previous meeting. The material at the ninth and tenth meetings is Expression (giving suggestion). At the ninth meeting, the teacher explained the giving suggestion material and gave several expressions related to the suggestion. Then the students will find their own example sentence suggestions.

At the tenth meeting, the teacher divides students into several groups, then the students are asked to make a dialogue about the suggestion by practicing directly using speaking. then the meeting always ends with the meeting ending with prayer and greetings.

\section{Meeting 11 and 12}

The eleventh and twelfth meetings will be held on January 24 and 312020 from 14:40 to 15.30. The initial activity begins with opening greetings, a prayer led by one of the students, and other activities such as in the initial activities in the previous meeting. The material at 
this meeting is "Expression (Asking and Giving Advice)". In this material the steps taken by the teacher are almost the same as the previous meeting, namely providing explanations and dividing students into several groups then the students are asked to have a dialogue in front of them. Then the meeting always ends with the meeting ending with prayer and greetings.

\section{Meeting 13}

The thirteenth meeting was not held due to training from the local fire department. This training aims to educate students to be alert and not mistaken in taking actions when fire occurs. This activity will be held on February 7 from 13.10 to 15.30 . This activity was attended by all students and students of Phatanakansuksa foundation School starting from kindergarten (Anuban), elementary school (Pra'thom), high school (Mattayeom).

\section{Meeting 14}

The fourteenth and fifteenth meetings will be held on February 14, 2020, at 14:40 to 15.30. The initial activity begins with opening greetings, a prayer led by one of the students, and other activities such as in the initial activities in the previous meeting. At this meeting, the teacher gives assignments to students regarding all the material that has been taught and evaluates the vocabulary given at each meeting. Then the meeting always ends with the meeting ending with prayer and greetings.

\section{Meeting 15 and 16}

The sixteenth meeting was held on February 21 and 282020 from 14:40 to 15.30. At this meeting, all teachers including researchers provided a review of all subjects starting from the first meeting. This review was conducted so that students were able to recall past material.

\section{Meeting 17}

The thirteenth meeting was not held because there were graduation events for grade 6 Mattayeom, grade 3 Mattayeom, and 6 Pra'tom. This activity was held on March 6, 2020, from 8.00 am to $16.10 \mathrm{am}$.

\section{Meeting 18}

This meeting was held on March 27, 2020, at this meeting the teacher gave a tryout or grid related to the preparation of the final class upgrade exam. The lattice is made based on the requirements for making a grid that represents the content of the curriculum. The grid is made briefly and clearly, the questions can be arranged according to the form of the questions.

\section{Conclusion}

The results of the implementation of classroom action research in the Mattayeom 4/2 Phatanakansuksa Foundation School's Real Work Lecture program show an increase in learning outcomes through a direct learning process applied by teachers/researchers. As for what is discussed here is the student learning outcomes during 18 meetings or one meter. The indicator of the success of this classroom action research is if the students' English learning outcomes from cycle I to cycle II which are reviewed from the final test of each cycle have an increase in the average score, which is above the Minimum Completeness Criteria standard set by the school, namely 75 in the Mattayeom class. 4/2 Phatanakansuksa Foundation School after applying the Scientific Approach Method. In the learning process, there were some improvements that occurred in students where based on the observations of students 'attitudes in the class during learning activities, this method was able to change students' learning attitudes and could increase student creativity and learning activities and foster a sense of mutual cooperation between students. In addition, students are more enthusiastic in participating in learning, marked by a sense of enthusiasm and discipline of students and the 
courage to ask and answer questions.

\section{References}

Basiroh, Z. (2017). Implementation of scientific approach and teacher affective learning strategy of PAI in increasing student learning achievement. MUDARRISA: Jurnal Kajian Pendidikan Islam, 9(2), 228-247.

Chu, S. K. W., Tse, S. K., \& Chow, K. (2011). Using collaborative teaching and inquiry project-based learning to help primary school students develop information literacy and information skills. Library \& Information Science Research, 33(2), 132-143.

Dessy, A. (2014). Langkahlangkah Melakukan R\&D (Research and Development), http://www.eurekapendidikan.com/ 2014/12/karakteristik-r-research-a nddevelopment.html

Firman, F., Baedhowi, B., \& Murtini, W. (2018). The effectiveness of the scientific approach to improve student learning outcomes. International Journal of Active Learning, $3(2), 86-91$.

Nugraha, I. S., \& Suherdi, D. (2017). Scientific approach: an english learning-teaching (ELT) approach in the 2013 curriculum. Journal of English and Education, 5(2), 120-135.

Regulation of the Minister of Education and Culture No. 81A year 2013.Implementasi Kurikulum Pedoman Umum Pembelajaran.

Santoso, B. (2010). Skema dan Mekanisme Pelatihan: Panduan Penyelenggaraan Pelatihan. Yayasan Terumbu Karang Indonesia.

Wicaksono, A., \& Roza, A. S. (Eds.). (2015). Teori Pembelajaran Bahasa: Suatu Catatan Singkat. Garudhawaca. 